\title{
In The Eye of the Beholder - Attitudes towards Visual Poetry in Latvian Literature
}

\author{
MĀRTIN̦Š LAIZĀNS
}

\begin{abstract}
Visual poetry in Latvian literature is still an extraordinary phenomenon. In this case, by extraordinary is meant its scarce appearance among the corpus of Latvian literary texts - only very few examples of it exist in Latvian literature even in the $21^{\text {st }}$ century, though it has gained a visible presence in other literatures of the world since at least the era of Modernist poetry, and experienced in most cases a turn of critical attitude towards it from disregard or denial to acceptance and consideration. At first evaluated only as a pastime on the margins of serious literature, since Apollinaire it has evolved into a serious genre of poetry and art of its own, and is no longer considered a childish game. Given this situation in contemporary criticism, it is quite a peculiar situation that Latvian literature and literary criticism still does not pay adequate attention to it, thus visual poetry has stayed an outsider genre up to this day.

In this paper a concise historical account of Latvian visual poetry will be given and some examples of visual poetry from various decades of Latvian literature will be given, as well as quotations from Latvian literary critics and scholars regarding visual poetry will be provided, in order to illustrate the overall situation in Latvian visual poetry and the possible reasons why it is still being mostly neglected and disregarded both by poets/artists and critics, though there seems to be slight indications of a visual turn.
\end{abstract}

Keywords: visual poetry; conceptualist poetry; avant-garde; multimedia art; digital art; Latvian literature

In this article I will shortly and concisely outline the development of Latvian visual poetry, in particular in the most recent decades. It must be said that overall there are not many examples of visual poetry in Latvian literature and there is no tradition, school or -ism ${ }^{1}$ developed regarding this genre of poetry,

1 A very recent exception to this is the so-called Preili Conceptualism (Preilu konceptuālisms) that has been created and developed by the Latvian poet Einārs Pelšs (1960); this "movement" has gained some momentum by attracting the younger generation of Latvian poets, as well as earning ample attention from the audience (a sold-out performance, an extremely rare occasion in contemporary Latvian poetry, on $4^{\text {th }}$ of January 2019).

DOI: https://doi.org/10.12697/IL.2019.24.2.12 
thus this account will focus on disparate but still significant examples of visual poetry ${ }^{2}$. It must also be noted that there are only two poetry collections in Latvian literature that consist of visual poems only (or at least these works can be considered as very closely tied conceptually to the techniques of visual poetics) - Mariagrammas (Mariagrammes, 2013) by Leons Briedis (1949) and Condom (2018) by Demon (a pseudonym for Einārs Pelšs). In addition to these, there are some collections from recent times that contain some visual poems or the visuality of the poems plays a significant role in the collections, e.g., Tumša stundā (In a Dark Hour, 2012) by Pèteris Draguns, Mìlākais têtis pasaulē (The World's Most Favourite Dad, 2016) by Einārs Pelšs, and other collections or publications in the press or literary magazines, nonetheless they cannot be called collections of visual poetry. Also the Latvian scholar of literature and folklore Janina Kursite has mentioned that there are very few examples of visual poems in Latvian poetry (Kursite 2002: 154). In addition to this observation, Latvian literary scholar Bronislavs Tabūns in his overview of the Modernist movements in Latvian poetry cites only one example of visual poetry in the chapter on Dadaism (Tabūns 2008: 109).

The origins of visual poetry in Latvian literature can be attributed to the works by Jānis Steiks (1855-1932). Against the backdrop of the Latvian literary scene of his time, his poetry is unordinary and unorthodox both with his heavy inclinations towards pseudoetymologies and his use of foreign languages, even hieroglyphs, as well as phonic structures and hymnic repetitions of letters and syllables. Furthermore, the structure and layout of his poems in some instances produce visual effects, and, taking into consideration all the mentioned characteristics of his poetry, it is a difficult task for the reader at times to understand the preferable, if there is one, reading direction of his poems, as well as the meaning of the poems in general - a proof of this hardship is also the vast commentaries provided for his selection of poems (Steiks 2003: 167-222). The most prominent use of visual elements is to be encountered in his poem Latvia's Opera (1921) (Steiks 2003: 113-116) where by continuous enhancement of visual components the poem arrives at a cross structure filled with words, letters, and visual symbols that can be read either Latava or Tâlava ${ }^{3}$, depending on the direction of reading.

2 A more detailed account of the examples of visual poems in Latvian literature can be found in my article about visual poetry in Latvian literature (Laizāns 2017).

3 A historical region of Latvia in medieval times that in later times gained a somewhat mythical character in Latvian popular consciousness; Latava is a wordplay on Tãlava that also includes the play on the stem 'lat-' that is a constituent part of both the words 'Latvians' and 'Latvia'. 
In The Eye of the Beholder - Attitudes towards Visual Poetry in Latvian Literature

One of the first examples of visual poetry that to some extent shows attitude towards it in general are the three visual poems by the Latvian poetess Valija Brutāne (1911-1990). These poems are included in the annual poetry collection of Soviet Latvia Dzejas diena (Poetry Day) of the year 1969. The first marker of the attitude towards visual poetry is the chapter of which they are a part - Satire, Humor and Parodies. This title of the section makes it clear to the audience that these visual poems Gulta (Bed), Galds un krēsls (Table and Chair), and Koks (Tree) (Brutāne 1969: 187-189) in the manner of poésie concrète are not to be taken too seriously. Also the epigraph chosen by Brutāne tells a lot about the perception of visual poetry - why not let poetry at times be playful... - those are the words of the Russian poet Alexander Voznesensky (Амексанар Вознесенский, 1898-1950).

These three poems are very simple examples of visual poetry as the text describes the objects mentioned in the title and the text takes the shape of the objects described. If Bed and Table and Chair do not show any signs of originality or interplay with other texts, then the poem Tree makes one wonder about certain things. The wording of the poem hints at an explosion - .. zal as / liesmas / šautru / auli / jautru / izšāvušos / no kukuržnainās zemes. (.. an arrow of green flame, a merry gallop shot from the lumpy earth ${ }^{4}$; Brutāne 1969: 189). This reading is reinforced by the shape of the poem - although the title says it is a tree, and it indeed looks like one, it is also very similar to the form of the explosion of an atomic bomb. This coincidence can be looked at from two perspectives. The first one is that the text of the poem describes an immense force of the tree, and of nature in more general terms, but in this case it is a creative, not a destructive one. Thus Brutāne creates a counterpart to a nuclear explosion, but puts it in the same shape, thus creating a sort of a ying-yang or contraria sunt complementa situation. The other aspect is that it might be a reminiscence of the iconic visual poem of the same shape by the American Beatnik poet Gregory Corso (1930-2001), who published his well-known poem The Bomb in 1958. It is hard to say if Brutāne was familiar with this poem by Corso, but these poems can still be compared. If Corso is direct in his critique of nuclear power, then Brutāne does it obliquely, not mentioning it in direct terms, but providing an opposition to it.

Regarding the poem by Corso, an interesting case must be mentioned in the context of translation/transfer of visual poems from one language to another, or even from one sign system to another (as will be discussed more in the

4 All the translations are by the author of the article; the translations are literal renditions of the Latvian text. 
paragpraph on NSRD and Boiko). In the case of visual poems, a lot of aspects have to be taken into account when rendering them into another language - the verbal and the visual, and by all means, also their interplay. The poem by Corso has been published in Latvian (Korso 2014: 18-19), the translator is Jānis Elsbergs (1969). With this particular example we can see how a translation of a visual poem can go wrong, not entirely, but still. If the textual component can be deemed true to the original, then the shape of the poem has been destroyed almost entirely - the nuclear explosion has been cut in two halves. This division damages the visual aspect of the poem as it hardly resembles the shape of the original, and provides a completely different visual experience to the percipient of the poem. It is hard to say if this decision by publishers was made due to typographic reasons (to fit the poem onto one spread without any changes to the size of the font, so it would conform to the font form and size of other texts in the magazine) or the nonchalance of the translator and editor due to lack of experience in preparing visual poems for publishing. The font having been mentioned, it is also necessary to mention that in the case of visual poems, the font should be retained, as it is an integral part that constitutes the poem. In the translation of Corso's poem, the font has been changed as well.

An example where the translator, in this case Klāvs Elsbergs (1959-1987), the brother of Jānis Elsbergs, has retained the font, thus not disrupting the visuality of the poem, is in the collection of poetry by Guillaume Apollinaire, among which are also some of his calligrammes (see Apolinērs 1985: 111-114 Mazais auto (La petite auto), 115 Nodurtā dūja un strūklaka (La colombe poignardée et le jet d'eau) (both translated in full), 122 ([2 ${ }^{e}$ Canonnier conducteur $]$ ), 123 ([Du coton dans les oreilles]) (both in partial translation and without title)). The publishing of Apollinaire's poetry in 1985 can be deemed as the first introduction of visuality into Latvian poetry that was taken seriously, not as a satirical act as it is in the case of Brutāne. Around this time also the first serious examples of Latvian visual poetry appeared, and they were produced by visual and performance artists, e.g., the NSRD (Nebijušu Sajūtu Restaurēšanas Darbnica, Workshop for the Restoration of Unfelt Feelings), a duo consisting of architect and DJ Hardijs Lediňš (1955-2004) and performance artist and poet Juris Boiko (1954-2002). What is remarkable in some of the visual poems by either Boiko himself or in collaboration with Ledinšs, is that also audial elements expressed by visual or verbal means are added to their poems - musical notation in their poems (Boiko 2005: 107-108), indications of sound volume by font sizes (Boiko 2000: 69), thus a musical score without any notation, but only 
In The Eye of the Beholder - Attitudes towards Visual Poetry in Latvian Literature

with verbal and typographical means ${ }^{5}$ is created, or the effect of a sound wave is produced by both shaping the poem as a bell and spreading or blending the text as to imitate the effect of wave spreading and interference (Boiko 2000: 50). These examples also show that in the case of visual poems, if the poem is being read aloud, it becomes a relatively supplementary poem to the visual original, if the audience sees the poem, or a completely different poem, if the audience does not see it (as will be seen from some examples by Briedis), or it is a poem that cannot be read aloud at all, only to be seen (as will be evident from some examples by Godiñ̌s and Pelšs).

Along with Corso's Bomb in Latvian, also the fragment of (Boiko 2005: 107) shows, that there should be embraced a different type of approach in publishing visual poems - the macron over the letter $A$ in one instance coincides with the notation line, thus leaving to open interpretation if the $\bar{A}$ (A with a macron) that goes throughout the fragment suddenly changes to A (A without a macron) or not. This could be considered a minor carelessness on the part of the publisher and proof-reader of the collection when publishing the text, which does not retain all the visual (and in this case even audial) subtleties in the final edition, which are transferred from a manuscript or a typescript.

Before turning to an in-depth discussion of some eminent examples of Latvian visual poetry, some poets must be mentioned who will not be examined in this article, but who can certainly be of interest for researchers of visual poetry to look into. Elements of visuality have been used by Eduards Aivars (a pseudonym for Aivars Eipurs, 1956) in his collections Ainava kliedz (The Landscape Screams, Aivars 1996a), jā (yes, Aivars 1996b) and Es pagāju (I Went, Aivars 2001). In one of his poems without a title (Aivars 1996a: 7), the distances between the words in context with the contents of the poem - the flying of a kite - do not show the shape of the described object, but illustrates the process, as if literally making a verbal snapshot, and it is possible to interpret this poem as a reference to the famous words of Horace - ut pictura poiesis (Horatius 2008: 307, line 361), which are also attributed to Simonides

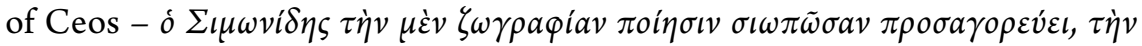

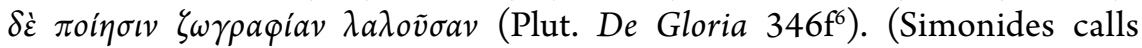

5 A certain proof of this can be the recording of this poem into a soundpiece - one can hear it in their album Sarkanie rakordi (Red Rachords, 1989, available on: http:// pietura.lv/nsrd/?grupa=nsrd\&disk=sarkanie_rakordi); the soundpiece has various versions, the $4^{\text {th }}$ and the $14^{\text {th }}$ track on the aforementioned album, where these tracks consist only of constant repetition of $z \bar{u} z \bar{a} / t \bar{t} t \bar{i} t \bar{i}$.

6 Available in Plutarch 1936. 
painting silent poetry, and poetry speaking painting $\left.{ }^{7}\right)$. In this instance, Aivars in a way develops this sentence in a literal sense and represents it nonmetaphorically - poiesis pictura est or reversely - pictura poiesis est, which in the case of visual poetry is also true as it is not possible to bring out the verbal or the visual as the principal one. The Latvian poet and translator Uldis Bērziñš (1944) also integrates some visual elements into his poems (Bērziñ̌ 2004: $326,560)$, the Latvian poetess Liāna Langa has produced some visual poems (Langa 1997: 37, 38, 50), in the poetry collection Tumšā stundā (In a Dark Hour, Draguns 2012) the text of the poems is in a different direction for each poem, also the font sizes differ, also the untitled poems have different markers in the place of the title (e.g., ///, \#\#\#, = = = and others in place of the usual ${ }^{* * *}$ ), and also the Latvian artist and poet Žebers (1958, real name Andris Breže) in his collection Blaknes (Side-effects, 2007) uses images not as a paratext or an illustration for the text, but makes them an essential part of the poem, e.g., he uses road signs in a series of collages and reinterprets them with the help of his texts (Žebers 2007: 85-98). Visuality has also been used by the Latvian graphic artist Luize Lote Nežberte (1998) where by adding layers of text and other visual symbols, she rewrites a poem (Nežberte 2017: [50]) by the Latvian poet Marts Pujāts (1982), adding a visual noise that makes the original poem almost illegible.

To turn to examples that show a more serious approach to visuality, one should mention some visual poems by Guntars Godinšs (1958), published in the selection of his poetry $C V$ (Godiñs 2008). With the employment of visual means in his poetry cycle Poetica (Godiñš 2008: 116-119, first published in his collection Ënu nesēji (Bearers of Shadows) in 1993), he returns to the same old question of Aristotle's and Horace's poiesis and the ars poetica in general, at least in the context of Latvian poetry. One of the most striking examples that illustrates the postmodern condition, the presence of wind of change in regard to political regimes, the reevaluation of traditional and canonical values, is his Latviešu tautasdziesma (Latvian Folksong, Godinš 2008: 119), that represents the Latvian folksong as an empty rectangle - a sort of Latvian take on the world-renowned and iconic painting Чёрный супрематический квадрат (Black Square) by Kazimir Malevich (Казимир Мамевич). This approach raises many questions. The daina (synonym for Latvian folksong) asks if one of the cornerstones of Latvian culture is still capable of the inspirational force that has been attributed to it, or has it become an empty canvas ready for new content, or it points out that no contemporary content can be inserted in the

\footnotetext{
Translated by W. Goodwin, in Plutarch 1847.
} 
In The Eye of the Beholder - Attitudes towards Visual Poetry in Latvian Literature

eternal and supernatural epic form of Latvian poetic expression. It can also ask whether all Latvian folksongs are basically the same, maybe leaving the contemporary audience indifferent to them. Many other ways of interpretation are also possible. Thus Godiņš is among the first Latvian poets who employ visual means in their poetry with a conceptually conscious approach, thus making something that looks the simplest possibly the hardest for a straight and narrow interpretation. Later in the article the visual transformations of the sonnet will be discussed and Godiñ̌s will be mentioned again.

To further illustrate how the possibilities of visual poetry can still be used both playfully and seriously by the same poets, the poem Man ir ko teikt (I Have Something To Say, Godinšs 2008: 226) must be mentioned. The poem consists of the letters of the Greek alphabet and some visual icons that are usually associated with Windings. In each line of the poem there is also one capital letter in the Latin alphabet that read vertically together makes up the same sentence of the title-M A N I RKO TE I KT (I H A VES O M E T H I N G T O S A Y, Godiņš 2008: 226). Apart from this sentence, all the other letters do not make any sense, at least verbally. Still, taken as a whole, this poem can be interpreted as an expression of one's opinion on poetry - it seems that it is an ironic stance, which supposes that poetry is meaningless and nonsensical, that the meaning of every poem is just made up by the reader independently from the author, thus it does not matter what kind of words (or other means of expression) the poet puts in his work. Also the date and place of composition reinforces the ironical atmosphere -06.02.1916. in Zürich - just a day after the opening of the Cabaret Voltaire. Besides, the use of the (Ancient) Greek alphabet might also tempt one to interpret the poem so that contemporary poetry (but not only) is just like Ancient Greek was to Western Europe in medieval times (and sadly enough also for contemporary Europe) - Graecum est, non legitur, which is recreated by Godiņš as - poetice est, non intelligitur, thus making poetry an autotelic game.

In addition, two remarks should be made in the context of this poem by Godin,š. One is that Juris Kronbergs (1946) has created an answer-poem Guntaram Cìrihē (To Guntars in Zürich, Kronbergs 2016: 61) to this work by Godiñš ${ }^{8}$. In his reply Kronbergs uses the Greek alphabet in an even more distorted manner, adding as the date of composition the first of April, the international April Fools' Day. The other aspect to mention is that Pelšs illustrates the same idea (I have something to say, no matter what it is) in his poem that repeats nav svarigi ko rakstit, bet - kä (it doesn't matter what to write,

8 It must also be mentioned that Godiņš is the editor of these two collections by Kronbergs. 
but how, Pelšs 2018: $\left.[61-68]^{9}\right)$, using a different font, language or symbol system in each line, in total spanning 8 pages. These three examples use visual means to approach the question of the status of poetry - is it just a game that has no meaning or perhaps the visuality is used as an inferior tool (at least in these instances by Godiņš and Kronbergs) that has no place in verbal poetry. Another possibility is that the visuality catches the attention of the audience more aggressively, thus the poem and the possible questions it raises make a greater impact.

Along the examples already discussed, also the sonnet, which has stood firmly as one of the classical standards of Western poetry for many centuries, should be mentioned in the context of Latvian visual poetry. It seems that the sonnet is a favourite among contemporary Latvian poets in the realms of visual poetry, being a handy tool to reconsider, reinterpret, and show the role of classical poetry, as well as poetry in general, in contemporary society. As already mentioned, Godinš uses the sonnet form in a visual poem consisting only of lines with no text in them - Sonets ar linijām (Sonnet with lines, Godiňš 2008: 116). It raises the same questions as Latviešu tautasdziesma, but in a wider context. Also the prolific Latvian poet and translator Leons Briedis (1949) has reused the form of the sonnet extensively. As a translator of canonical sonnets (e.g., Petrarca's Il Canzoniere, Briedis 1981), he has also produced a voluminous collection of sonnets, 365 in number, Agrais pavasaris (Early Spring, 2005), where each one of them is devoted to a real or fictional lady by her admirer. In this collection he plays with the layout of the text, but nothing that could be called visual poems is produced. But in his collection of visual poems Mariagrammas (Mariagrammes, 2013), he goes one step further and creates several visual sonnets (Briedis 2013: 7, 11,89). One of the most striking examples is his Tukšais sonets (Empty Sonnet, Briedis 2013: 89). It is a square where the text goes around, taking rectangular turns, and the centre of this square sonnet is empty. It could be argued that Briedis also asks similar questions to those raised by Godiñ̌ in his Latviešu tautasdziesma - maybe the sonnet as a form (and other classical forms) has had its time in the poetry world and now it can be announced dead, or in this case empty, as there is only the text on the surface, but that is only a shell which covers a void, and maybe that is the case with every sonnet. It should also be taken into consideration that the void engulfing the text is in perfect metrical design, thus taking the discussion even further, asking if the tradtitional forms of poetry and genres should be put into different shapes. As discussed earlier, this classical character of the verbal

\footnotetext{
9 The edition has no page numbering.
} 
In The Eye of the Beholder - Attitudes towards Visual Poetry in Latvian Literature

aspect in this collection makes perfect sense for the audience if the poem is read aloud, which is not the case with most of the visual poems discussed in this article. With the reshaping of traditional forms of poetry Briedis does not create any particular tension with more traditional and verbal approaches to poetry.

In the company of Latvian sonnet transformers also Einārs Pelšs should be mentioned. With his poem $p^{\circ}$ (Pelšs 2016: 11) that consists of repetitions of the same equivocal symbol, thus producing a sonnet pattern, he also raises several questions about the role of the sonnet and poetry in general. The Latvian poet and literary critic Artis Ostups (1988) calls this symbol self-sufficient and also a possible abbreviation for the slang word pofig (from Russian: it doesn't matter) or pohuj (a ruder version of the former), that in turn serves as a sign for the liberal attitude of Pelšs towards the medium of poetry (Pašpietiekamas zimes iespaidu atstāj "po", kuras atkārtojumi veido veselu sonetu (11. lpp.) un kuru var izlasìt arī kā "po" - saīsinājumu vārdam "pofig" vai "pohuj" un lìdz ar to arī kā apzīmējumu Pelša brivajai attieksmei pret dzejas mediju, Ostups 2016). Another Latvian poet and critic Aivars Madris (1987) in the same article calls this invention by Pelšs a ponnet (ponets, Ostups 2016). At least the sonnets by Godiňš and Pelšs are open to unlimited interpretations, where every reader can either put in his own content or reflect upon the role of poetry in the $21^{\text {st }}$ century $y^{10}$.

After the anaysis of the tranformations of the sonnet into visual poems, it is now reasonable to turn to the two most prolific producers of visual poetry, who were introduced in the previous paragraph - Briedis and Pelšs. The collection by Briedis was something completely unique and never before seen in Latvian literature. Still, his attempts to introduce visual poetry to the Latvian readership did not gain much approval neither from the readers nor the critics. And there is a good reason for that. Although praised for his daring attempts, there are several imperfections or conceptual miscalculations in his collection that his critics point out. For example, Arita Strode-Kḷavina (1989) in her review of the collection (Strode-Kḷavina 2013), though praising Briedis for his courage to break new ground, indicates that Diemžè grūti sameklèt ko poètiski, mākslinieciski un saturiski augstvērtīgu, novatorisku vai vienkārš̀i skaistu. Un nākamajos. Un aiznākamajos... (Unfortunately also in the next twenty or so poems it is hard to find something that would be of high value,

10 The sonnet by Pelšs is indeed open to widely different interpretations that can neither be confirmed nor overturned when given as a close-reading exercise both to undergraduate and graduate students, leaving the audience with a plethora of opinions of what this sonnet could mean. 
innovative or simply beautiful poetically, artistically or content-wise. Also in the next ones. And in the next ones after the next ones..., Strode-Kl̦avina 2013).

Throughout this collection, Briedis uses a number of canonical shapes that are associated with visual poetry that stem back to to first surviving examples from Ancient Greece (e.g., an hourglass (Briedis 2013: 39); this is one of the shapes that seem to be a trap for poets who are inexperienced in visual poetry, as it can be encountered also in (Godiņš 2008: 104) and is used by Daiga Lapāne (cited as an example in: Kursite 2002: 154) - they use this clichéd shape without any conceptual originality), but overall he does not provide any conceptual manouvers with the employment of shapes and visual figures, but just puts traditional and classical (i.e., metrical and rhyming stanzas), even folksongs into shapes that are unusual for these types of poetry. The banal shapes and amateurishly used effects of computer graphics rather obstruct the experience of the poems than enhance it. On the whole, it seems that Briedis in this collection just wanted to put usual textual poems into different shapes without any further goal, thus the interplay between the textual and visual is rather lacking or the visual is of secondary and not equal significance in the poems. One can argue that Briedis in a way follows in the footsteps of Brutāne, in particular if we compare the epigraph used by Brutāne with one example by Briedis. In his poem Spèle (Game, Briedis 2013: 79) the core idea also supported by the text is that this approach to poetry to him is Vien spèle, spèle, spēle, spèle, spèle, spèle (Just a game, a game, a game, a game, a game, a game). The sextuple repetition of game in the first line and throughout the poem in addition that the same text is being repeated on each face of a cube that seems to be a dice, reinforces this interpretation.

The other poet whose approach relies strongly on visuality, but, in contrast to most of the examples mentioned, with a consciously driven conception, is Einārs Pelšs. After the publishing of his Mīlākais tētis pasaulè (The World's Most Favourite Dad) in 2016 and even more so after Condom (2018), Latvian poetry scene is not the same any longer, it is unimaginable not to take into account the poetics of Pelšs, it is a contemporary milestone of Latvian poetry. Although Pelšs had published his first collection in 1987, that was in no way radical or experimental in its poetics, he was silent for 25 years, and his comeback in a completely new form was marked by the publication of Mìlākais tētis pasaulē, devoted to his late son, ice hockey player Kristiāns Pelšs. The Latvian poet and literary critic Raimonds Kirkis (1997) comments on the poetry of Pelšs thus: Domāju, ka Eināra Pelša dzeja ir diezgan novatoriska un tas ir jaunatklājums, ja ne globālā mērogā, tad vismaz Latvijā. (In my opinion the poetry by Pelss is quite innovative and it is a discovery, if not on a global scale, then 
In The Eye of the Beholder - Attitudes towards Visual Poetry in Latvian Literature

certainly in Latvia, Kirk,is 2019). Furthermore, Artis Ostups in his review of this collection remarks, that this kind of poetry makes us dream that there still can be unexplored territory in poetic expression, although it does not seem that the experiments by Pelšs will ignite a revolution in Latvian poetry (Ostups 2016).

The collection Condom can hardly be called a collection of poetry, it is rather an artwork as it uses and is influenced by various media and all kinds of literary, art and cyberspace media genres - lo-fi digital art, creative repurposing of computer programs, cyberfauvisme, single line art, a collage of various avantgarde techniques and modernist movements etc. His Condom does not leave anyone indifferent, and critics and audience tend to split into two - those who see it as a breath of fresh air in Latvian poetry (Vērdiñš 2016, Ostups 2016, Kirķis 2018, Madris 2018, Laizāns 2018) and those who are not so appreciative (Ratniece 2018, Vecgrāvis 2018) rather evaluating the work by Demon as a recreation of the explorations by earlier modernists and avantgarde artists, without any new cotributions (Dēmona veikums atkārto šos meklējumus, neko bütisku žanram nepiepulcējot .., Vecgrāvis 2018: 10), and that this collection will be a disappointment for those who love traditional and classical poetry (.. vilsies tie, kuriem mīla ir tradicionālà dzeja, tās formas, pasniegšanas stils un saturs, Ratniece 2018) and that ir rather creates an impression of an Olivier ${ }^{11}$ salad (.. rodas rasola iespaids, Ratniece 2018 ).

However it may be, almost all of the works in Condom can be viewed from the same perspective as his ponnet - they have no stable centre of reference from which certain and firm interpretations could be made as they all are provoking self-reflexions on the genres (although it is impossible to add any of the material by Pelšs to any certain genre), conscious irony about poetry and art. The same poetics as in Mīlākais tētis pasaulē and Condom can be seen on his facebook page (https://www.facebook.com/einars.pelss), where a lot of new material is being published quite regularly, along with translations of mostly Russian classical and avantgarde poets, thus showing the fusion of the verbal with other media. In an interview with a group of Latvian poets Pelšs himself calls his collection Mìlākais tētis pasaulē an example of mäksla mākslai (art for art's sake, Pelšs $2016 \mathrm{~b}$ ), that gets intensified to levels that create a nuclear fusion, at least in Latvian poetry, in Condom.

In conclusion, several observations can be made about the state of Latvian visual poetry and the attitudes towards it. As already mentioned in the introductory passages, there are not a lot of examples of visual poetry in Latvian literature, nonetheless these scarce examples allow us to make some remarks

11 Also translated as 'Russian salad'. 
about the attitude towards visual poetry. Some poets use it only as an unserious form of expression, some use it for more serious goals, some use it in both ways. Still, the production of visual poems is occassional for most of the poets mentioned in the article. The use of visual means in poems helps to reconsider the role of poetry, mostly leaving it as an open question without any determined answer. In the last years the popularity of visual poetry has grown and mostly thanks to the efforts of one man only - Einārs Pelšs. Taking into account his works and the reviews of them, it seems that now there has been a turn for the better in attitude towards visual poetry in Latvian literature, making also visual poetry a force that should be reckoned with.

\author{
Mārtiņš Laizāns \\ martins.laizans@lu.lv \\ Latvijas Universitāte \\ Dzirnavu iela 72-8 \\ LV-1050, Riga \\ LATVIJA / LATVIA
}

\title{
Bibliography
}

Aivars, E. 1996a. Ainava kliedz. Rīga: Raka.

Aivars, E. 1996b. jā. Rìga: Raka.

Aivars, E. 2001. Es pagāju. Rìga: Preses nams.

Apolinērs, G. 1985. Gājiens. Rīga: Liesma.

Bērziňš, U. 2004. Dzeja. Rīga: Atēna.

Boiko, J. 2000. Dziesmas un dzejas. Rīga: Preses nams.

Boiko, J., Lediñš, H. 2005. ZUN. Rīga: Jumava.

Briedis, L. et al. 1981. Agrā renesanse. Rìga: Zvaigzne.

Briedis, L. 2005. Agrais pavasaris. Rīga: Minerva.

Briedis, L. 2013. Mariagrammas. Rīga: Neputns.

Brutāne, V. 1969. Gulta. Galds un Krēsls. Koks. - Dzejas diena. Rīga: Liesma. 187-189.

Draguns, P. 2012. Tumšā stundā. Rìga: Neputns.

Godinš̌, G. 2008. CV. Rīga: Jāṇa Rozes apgāds.

Horatius. 2008. Opera. Berlin: Walter de Gruyter.

Ķirķis, R. 2019. Nelīp klāt patoss. - https://www.diena.lv/raksts/kd/intervijas/ intervija-ar-dzejnieku-raimondu-kirki.-nelip-klat-patoss-14214143 (11.02.2019).

Ķirķis, R. 2018. Iespiests jābūt jābūt iespiests. - www.satori.lv/article/iespiests-jabutjabut-iespiests-preilu-konceptualisms (16.03.2018).

Korso, G. 2014. Bumba. Latvju teksti, 3. Rīga: Latvijas Literatūras centrs, 18-19.

Kronbergs, J. 2016. Uz balkona / Bet ja visu laiku... Rìga: Dienas Grāmata.

Kursīte, J. 2002. Figūrvārsmas. Konkrētā dzeja. Dzejas vārdnīca. Rīga: Zinātne, 154, 213-214. 
In The Eye of the Beholder - Attitudes towards Visual Poetry in Latvian Literature

Laizāns, M. 2017. Vizuālā dzeja latviešu literatūrā. - Akadēmiskā dzīve, 53. Rīga: LU Akadēmiskais apgāds, 46-59, https://www.lu.lv/par-mums/lu-mediji/zurnali/ akademiska-dzive/arhivs/53-numurs/ (23.10.2019).

Laizāns, M. 2018. Skatāmpanti. [Seerhymes] - https://www.ubisunt.lu.lv/zinas/t/ $23246(23.03 .18)$

Langa, L. 1997. te debesis, te ciparnīca. Rìga: Apgāds Daugava.

Madris, A. 2018. Tīrās dzejas kritika. - rmm.lv/2018/02/tiras-dzejas-kritika-diskusijapar-einara-pelsa-demon-dzejas-krajumu-condom (12.02.2018).

Nežberte, L. L. 2017. Ķilis. Rīga: Āgenskalna Valsts gímnāzija. [50], http://avg.lv/cms/ files/files/2017-05-18/KILIS-3.pdf (18.05.2017).

Ostups, A. 2016. Paragrāfi par Pelša jaunāko dzeju. - www.satori.lv/article/paragrafipar-pelsa-jaunako-dzeju (27.05.2017).

Pelšs, E. 2012. S. Rīga: Iespēju grāmata.

Pelšs, E. 2016a. Mì̄ âkkais tētis pasaulē. Ozolnieki: Literature without borders.

Pelšs, E. 2016b. Sarkangalvīte. - http://www.punctummagazine.lv/2016/08/23/ sarkangalvite (23.08.2016).

Plutarch. 1874. Plutarch's Morals. Boston: Little, Brown, and Company, http://www. perseus.tufts.edu/hopper/text?doc=Perseus\%3Atext\%3A2008.01.0236\%3Asect ion\%3D3 (23.10.2019).

Plutarch. 1936. Moralia. Cambridge, MA: Harvard University Press. 1936, http:// www.perseus.tufts.edu/hopper/text?doc=Perseus\%3Atext\%3A2008.01.0233\%3 Astephpage\%3D346f (23.10.2019).

Ratniece, S. 2018. Rotaḷas ar vizualitāti. - http://www.la.lv/rotalas-ar-vizualitati (13.03.2018).

Steiks, J. 2003. Izlase. Rīga: Zinātne.

Strode-Kḷaviṇa, A. 2013. Kaklamežgis. - https://www.ubisunt.lu.lv/zinas/t/42308/ (27.05.2017).

Tabūns, B. 2008. Modernisma virzieni latviešu literatūrā. Rīga: Zinātne.

Vecgrāvis, K. 2018. Dēmona prezis "reizē sūkā un nesūkā”. - Konteksts, 3, 10.

Vērdiņš, K. 2016. Einārs Dzejnārs. - www.diena.lv/raksts/kd/recenzijas/gramatas-_ milakais-tetis-pasaule_-recenzija.-einars-dzejnars-14141957 (27.05.2017).

Žebers. 2007. Blaknes. Rīga: Neputns. 